\title{
Metabolic syndrome in patients with hypertension attending a family practice clinic in Jordan
}

\author{
N. Yasein, ${ }^{7}$ M. Ahmad, ${ }^{2}$ F. Matrook, ${ }^{3}$ L. Nasir ${ }^{4}$ and E.S. Froelicher ${ }^{5}$
}

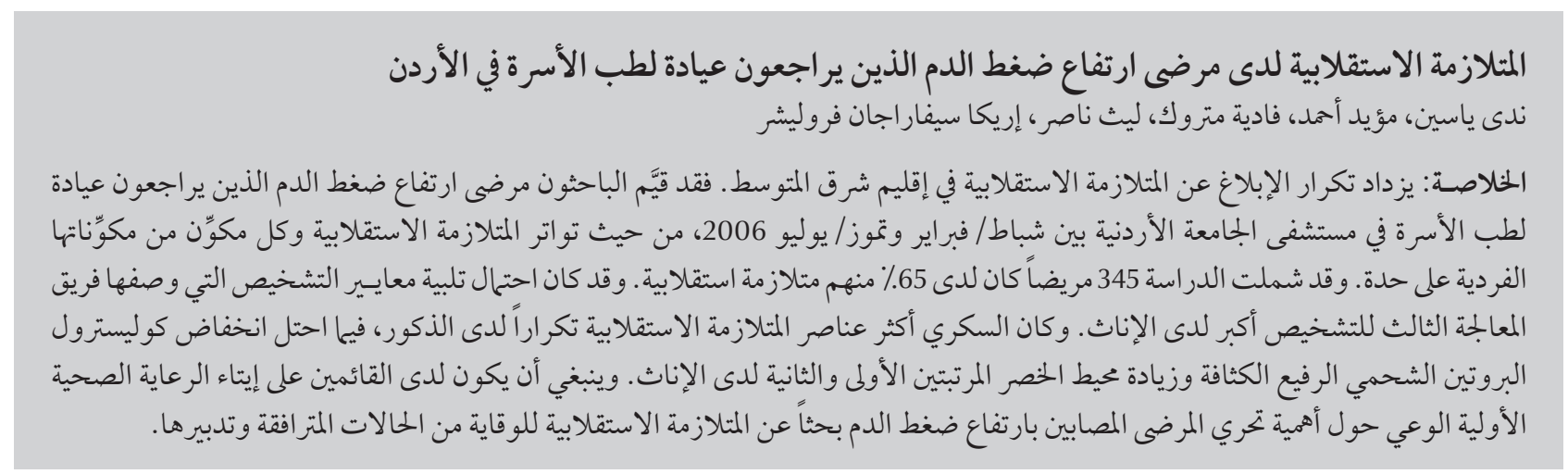

ABSTRACT Metabolic syndrome is being reported more frequently in the Eastern Mediterranean region. Patients with hypertension attending family practice clinics in the University of Jordan Hospital between February and July 2006 were assessed for the frequency of metabolic syndrome and its individual components. Of 345 patients studied, 65\% had metabolic syndrome. Females were more likely to meet Adult Treatment Panel-III criteria for the diagnosis. Diabetes mellitus was the most frequent component of metabolic syndrome in males, while low serum high-density lipoprotein cholesterol and high waist circumference ranked first and second in females. Primary care providers should be alert to the importance of screening patients with hypertension for metabolic syndrome to prevent and manage these combined conditions.

Le syndrome métabolique chez des patients hypertendus fréquentant un service de médecine familiale en Jordanie

RÉSUMÉ Le syndrome métabolique est couramment observé dans la Région de la Méditerranée orientale. La fréquence du syndrome métabolique et ses composants individuels ont été évalués chez des patients hypertendus ayant fréquenté le service de médecine familiale de l'Hôpital universitaire de Jordanie entre février et juillet 2006. Sur les 345 patients ayant participé à l'étude, 65 \% présentaient un syndrome métabolique. Les femmes satisfaisaient davantage les critères de diagnostic du groupe d'experts américains de l'Adult Treatment Panel-II/ que les hommes. Le diabète sucré était le composant le plus fréquent du syndrome métabolique chez les hommes, tandis que chez les femmes, un faible taux sérique de cholestérol des lipoprotéines de haute densité et un large tour de taille étaient respectivement le premier et le second composants le plus fréquents. Les prestataires de soins de santé primaires devraient être attentifs à l'importance du dépistage du syndrome métabolique chez les patients souffrant d’hypertension afin de prévenir et de prendre en charge la concomitance de ces pathologies.

${ }^{7}$ Department of Family and Community Medicine; ${ }^{2}$ Department of Clinical Nursing, Faculty of Nursing; ${ }^{3}$ Department of Family Medicine, University of Jordan, Amman, Jordan (Correspondence to N. Yasein: Nyasein_85@hotmail.com).

${ }^{4}$ American Board of Family Medicine, University of Nebraska Medical Center, Nebraska, United States of America.

${ }^{5}$ Departments of Physiological Nursing and Epidemiology and Biostatistics, Schools of Nursing and Medicine, University of California San Francisco, San Francisco, United States of America.

Received: 22/10/07; accepted: 27/03/08 


\section{Introduction}

The metabolic syndrome is a cluster of risk factors for cardiovascular disease and diabetes that includes hypertension, glucose intolerance, dyslipidaemia and abdominal obesity. High blood pressure is considered one of the key features of metabolic syndrome $[1,2]$. The European Society of Cardiology clinical guidelines for management of hypertension stress the importance of identifying patients with metabolic syndrome as a group at high risk for the development of cardiovascular disease [3]. Although women tend to have fewer cardiovascular events, the populationattributable risk for hypertension is higher for women than men due to their longer life expectancy and the rise in the incidence of hypertension with age [4].

Despite few studies in the Region, metabolic syndrome is being reported more frequentlyin the Eastern Mediterranean Region (EMR) [5-7]. Furthermore, a higher frequency of metabolic syndrome has been observed among females than among males $[8-11]$.Jordan is a prototype of an EMR country that has undergone rapid cultural transition within the past 30 years. This is reflected in lifestyle changes affecting traditional diets and levels of physical activity. Several surveys have documented a high prevalence of diabetes, hypertension and obesity in the Jordanian population [12,13], but none has assessed the frequency of metabolic syndrome and its components among hypertensive patients in Jordan.

This study aimed to determine the frequency of the metabolic syndrome and its individual components in men and women with hypertension in Jordan.

\section{Methods}

A cross-sectional design was used in this study carried out from February to July 2006.

\section{Sample}

A total of 345 Jordanian patients with hypertension (143 males and $202 \mathrm{fe}$ males) aged $\geq 25$ years attending the family practice clinic at the University of Jordan Hospital were screened for the presence of metabolic syndrome. The sample was consecutively selected by a research nurse from patients who visited the clinic over the study period; 5 patients/day, 3 times/week, were selected to be included in the study.

The inclusion criteria were men and women age $25+$ years, with a diagnosis of hypertension. Patients were classified as hypertensive based on the recorded readings in their notes. At this hospital blood pressure is usually measured in the sitting position by the clinic nurse and the mean of 3 readings separated by a 1 minute interval is recorded in the file as the patient's blood pressure. Hypertension was defined as a systolic blood pressure $\geq 135 \mathrm{mmHg}$ and/or a diastolic blood pressure $\geq 85 \mathrm{mmHg}$ [1], repeated 2-3 times over a 6-week interval or if the patient was already on antihypertensive medication. Patients not meeting these criteria or not willing to give consent to participate in the study were excluded.

All patients provided informed consent and the study was approved by the University of Jordan Hospital research ethics committee.

\section{Data collection}

A data collection form was used which included: personal demographic data (age, sex, physical activity and current smoking habit); history of type 2 diabetes mellitus; fasting lipid profile [total cholesterol, high-density lipoprotein cholesterol (HDL-C) and triglycerides (TG) ]; and fasting plasma glucose level.

Anthropometric measurements (weight, height and waist circumference) were also recorded. Height was measured to the nearest $0.5 \mathrm{~cm}$ using a stadiometer. Weight was recorded to the nearest $0.1 \mathrm{~kg}$ with the patient barefoot and wearing light clothing using a mechanical beam balance scale, calibrated regularly. Waist circumference was measured using a steel measuring tape, at the point halfway between the lower border of the ribs and the iliac crest in a horizontal plane. Two measurements were made and recorded to the nearest $0.5 \mathrm{~cm}$. If the variation between the 2 measurements was greater than $2 \mathrm{~cm}$, a third measurement was taken. The mean of the 2 closest measurements was then entered into the data collection form. A patient was considered obese if his/ her calculated body mass index (BMI) (weight/height ${ }^{2}$ ) was $\geq 30 \mathrm{~kg} / \mathrm{m}^{2}$ [14]. Abdominal obesity was diagnosed if the waist circumference exceeded $102 \mathrm{~cm}$ in males and $88 \mathrm{~cm}$ in females [1].

Physical activity was assessed during a personal interview as follows: "during the past year have you been exercising at least 5 times per week, walking, jogging, swimming, aerobics for more than one half hour per session?" If the paricipant met this criterion s/he was coded as an exerciser and, if not, as a non-exerciser. Anyone who currently smoked any number of cigarettes for any length of time was defined as a current smoker.

All laboratory investigations were done in the University of Jordan Hospital laboratories using an autoanalyser (Cobas Integra 400/700 clinical system, Roche, Switzerland). The laboratory standards and cut-off points used complied with the International Federation of Clinical Chemistry. Dyslipidaemia was defined as $T G \geq 150 \mathrm{mg} / 100$ $\mathrm{mL}(1.7 \mathrm{mmol} / \mathrm{L})$ for both sexes; and HDL-C $<40 \mathrm{mg} / 100 \mathrm{~mL}(1.04$ $\mathrm{mmol} / \mathrm{L})$ in men and $<50 \mathrm{mg} / 100 \mathrm{~mL}$ $(1.29 \mathrm{mmol} / \mathrm{L})$ in women [1].Apatient was classed as having diabetes based on the medical history recorded in the file. At the family practice clinics, diabetes is defined as fasting blood glucose $\geq 110$ $\mathrm{mg} / 100 \mathrm{~mL}(6.1 \mathrm{mmol} / \mathrm{L})$ or if the $\mathrm{pa}-$ tient is on treatment for diabetes [15]. 


\section{Definition of metabolic syndrome}

Three of the most common sets of criteria for the diagnosis of metabolic syndrome were used in this study: World Health Organization (WHO), National Cholesterol Education Program Adult Treatment Panel-III (ATP-III) and International Diabetes Federation (IDF) guidelines (Table 1).

\section{Analysis}

Statistical analysis was performed using SPSS, version 14. Descriptive statistics, chi-squared test and $t$-test were used to examine the data. All continuous variables were reported as mean, standard deviation (SD) and range throughout the study. Differences were considered significant at $P \leq 0.05$.

\section{Results}

The study sample consisted of 345 patients with hypertension: 143 (41.5\%) males and 202 (58.5\%) females. The mean age of the total group was 57.5 (SD 10.7) years, range 25-80 years. There were $52(15.1 \%)$ patients who reported current tobacco smoking, 273 (79.1\%) who took no regular exercise and 178 (51.6\%) who were obese (BMI $\left.\geq 30 \mathrm{~kg} / \mathrm{m}^{2}\right)$.

The frequency of risk factors for metabolic syndrome by sex using all 3 sets of criteria (WHO, ATP-III and IDF) are shown in Table 2. The total prevalence of obesity was lowest according to the WHO criteria (51.6\%), while it was highest according to IDF criteria (86.1\%). The prevalence of lowHDL-C was the same by ATP-III and IDF criteria (49.0\%), and was lowest by WHO criteria (21.7\%).

A comparison of the frequency of metabolic syndrome using the 3 different sets of criteria is shown in Table 3. The WHO criteria identified $26.9 \%$ of the sample with metabolic syndrome, with an almost equal frequency for males (27.3\%) and females (26.9\%). Both ATP-III and IDF criteria identified more than double the proportion of patients with metabolic syndrome than the WHO criteria $(65.2 \%$ and $64.9 \%$ respectively).

The frequency of patients with metabolic syndrome defined according to ATP-III criteria by sex is shown in Table 4. Among the subset of 225 patients who met the criteria for the diagnosis of metabolic syndrome, the rate was significantly higher in females (73.8\%) than males $(53.1 \%)(P<0.05)$, whereas among the patients without metabolic syndrome there were more males (46.9\%) than females (26.2\%).

Cross-tabulation of metabolic syndrome by ATP-III criteria with age was done. There was a statistically significant difference in age (categorized as $\leq 55$ and $>55$ years) between patients with metabolic syndrome [mean 59.02 (SD $10.46)$ years] and patients without metabolic syndrome $[$ mean $=56.69$ (SD 10.70) years] $(P=0.05)$.

Chi-squared testing was carried out to examine each of the 4ATP-III criteria in patients with metabolic syndrome (i.e. excluding hypertension which was the inclusion criterion for the sample) by sex.

Table 5 shows the frequency of each of the 4 ATP-III criteria (i.e. excluding hypertension which was the inclusion criterion for the sample) in patients with metabolic syndrome by sex. The most frequently identified aspect of the syndrome was high waist circumference

\begin{tabular}{|c|c|c|c|}
\hline \multirow[t]{2}{*}{ Risk factor } & \multicolumn{3}{|c|}{ Criteria set } \\
\hline & WHO & ATP-III & IDF \\
\hline Hypertension & $\begin{array}{l}\text { Taking antihypertensive } \\
\text { therapy and/or BP }>140 / 90 \\
\mathrm{mmHg}\end{array}$ & $\begin{array}{l}\text { Taking antihypertensive therapy } \\
\text { or } \mathrm{BP}>130 / 85 \mathrm{mmHg}\end{array}$ & $\begin{array}{l}\text { Systolic } \mathrm{BP} \geq 130 \text { or diastolic } \mathrm{BP} \geq 85 \mathrm{mmHg} \text {, } \\
\text { or treatment of previously diagnosed } \\
\text { hypertension }\end{array}$ \\
\hline Dyslipidaemia & $\begin{array}{l}\text { Plasma TG }>1.7 \mathrm{mmol} / \mathrm{L}(150 \\
\mathrm{mg} / \mathrm{dL}) \text { and } / \mathrm{or} \mathrm{HDL}<0.9 \\
\mathrm{mmol} / \mathrm{L}(35 \mathrm{mg} / \mathrm{dL}) \text { in men } \\
\text { and }<1.0 \mathrm{mmol} / \mathrm{L}(<40 \\
\mathrm{mg} / \mathrm{dL}) \text { in women }\end{array}$ & $\begin{array}{l}\text { Plasma TG }>150 \mathrm{mg} / \mathrm{dL}, \mathrm{HDL}- \\
\text { cholesterol }<40 \mathrm{mg} / \mathrm{dL} \text { in men } \\
\text { and }<50 \mathrm{mg} / \mathrm{dL} \text { in women }\end{array}$ & $\begin{array}{l}\text { Plasma TG }>150 \mathrm{mg} / \mathrm{dL}(1.7 \mathrm{mmol} / \mathrm{L}) \\
\text { or taking specific therapy for this lipid } \\
\text { abnormality or } \\
\text { low } \mathrm{HDL} \text {-cholesterol }<40 \mathrm{mg} / \mathrm{dL}(1.03 \\
\mathrm{mmol} / \mathrm{L}) \text { in men and }<50 \mathrm{mg} / \mathrm{dL}(1.29 \\
\mathrm{mmol} / \mathrm{L}) \text { in women }\end{array}$ \\
\hline Obesity & $\begin{array}{l}\mathrm{BMI}>30 \mathrm{~kg} / \mathrm{m}^{2} \text { and } / \mathrm{or} \\
\text { waist } / \mathrm{hip} \mathrm{ratio}>0.90 \mathrm{~cm} \\
\text { in men and }>0.85 \mathrm{~cm} \text { in } \\
\text { women }\end{array}$ & $\begin{array}{l}\text { Central obesity (waist } \\
\text { circumference }>40 \text { inches } \\
(102 \mathrm{~cm}) \text { in men and }>35 \text { inches } \\
(88 \mathrm{~cm}) \text { in women) }\end{array}$ & $\begin{array}{l}\text { Central obesity (waist circumference } \\
\geq 94 \mathrm{~cm} \text { for Europid men and } \geq 80 \mathrm{~cm} \text { for } \\
\text { Europid women, with ethnicity specific } \\
\text { values for other groups) }\end{array}$ \\
\hline Glucose & Diagnosis of type 2 diabetes & $\begin{array}{l}\text { Fasting blood glucose }>110 \\
\mathrm{mg} / \mathrm{dL}\end{array}$ & $\begin{array}{l}\text { Fasting blood glucose } \geq 100 \mathrm{mg} / \mathrm{dL} \text { ( } 5.6 \\
\mathrm{mmol} / \mathrm{L} \text { ), or diagnosis of type } 2 \text { diabetes }\end{array}$ \\
\hline $\begin{array}{l}\text { Requirements for } \\
\text { diagnosis }\end{array}$ & $\begin{array}{l}\text { Diagnosis of type } 2 \text { diabetes } \\
\text { plus any } 2 \text { other risk factors }\end{array}$ & Any 3 of the above disorders & Central obesity plus any 2 other risk factors \\
\hline
\end{tabular}

$B P=$ blood pressure $; G=$ triglycerides $; B M I=$ body mass index $; H D L=$ high-density lipoprotein . 


\begin{tabular}{|c|c|c|c|c|c|c|}
\hline $\begin{array}{l}\text { Table } 2 \text { Frequency of risk fac } \\
\text { hypertension according to t } \\
\text { National Cholesterol Educat } \\
\text { International Diabetes Fede }\end{array}$ & $\begin{array}{l}\text { rs for } \\
\text { crite } \\
\text { n Pro } \\
\text { tion }\end{array}$ & $\begin{array}{l}\text { tabolic } \\
\text { f the } 1 \\
\text { m Adu }\end{array}$ & $\begin{array}{l}\text { ndro } \\
\text { rld H } \\
\text { reatm }\end{array}$ & $\begin{array}{l}\text { Or } \\
\text { Pan }\end{array}$ & $\begin{array}{l}\text { izatio } \\
\text { II (ATP }\end{array}$ & $\begin{array}{l}\text { th } \\
\text { VHO), } \\
\text { and }\end{array}$ \\
\hline Protocol & & & & & & \\
\hline & No. & $\%$ & No. & $\%$ & No. & $\%$ \\
\hline WHO (1999) criteria & & & & & & \\
\hline Obesity $\left(\mathrm{BMI}>30 \mathrm{~kg} / \mathrm{m}^{2}\right)$ & 58 & 40.5 & 120 & 59.5 & 178 & 51.6 \\
\hline High TG & 67 & 46.9 & 104 & 51.5 & 171 & 49.6 \\
\hline Low HDL-C & 29 & 20.3 & 46 & 22.7 & 75 & 21.7 \\
\hline Diabetes mellitus & 46 & 32.2 & 57 & 28.2 & 103 & 29.9 \\
\hline ATP-III (2001) criteria & & & & & & \\
\hline Obesity (high WC) & 74 & 51.7 & 170 & 84.2 & 244 & 70.7 \\
\hline High TG & 67 & 46.9 & 104 & 51.5 & 171 & 49.6 \\
\hline Low HDL-C & 55 & 38.5 & 115 & 56.9 & 170 & 49.0 \\
\hline Diabetes mellitus & 46 & 32.2 & 57 & 28.2 & 103 & 29.9 \\
\hline IDF (2005) criteria & & & & & & \\
\hline Obesity (high WC) & 117 & 81.8 & 180 & 89.1 & 297 & 86.1 \\
\hline High TG & 67 & 46.9 & 104 & 51.5 & 171 & 49.6 \\
\hline Low HDL-C & 55 & 38.5 & 115 & 56.9 & 170 & 49.0 \\
\hline Diabetes mellitus & 46 & 32.2 & 57 & 28.2 & 103 & 29.9 \\
\hline
\end{tabular}

$W C=$ waist circumference $; G=$ triglycerides $; B M I=$ body mass index $; H D L-C=$ high-density lipoprotein cholesterol.

(87.6\%). Diabetes mellitus was the most common criterion in males with metabolic syndrome. In females, the combination of low HDL-C level and high waist circumference was the most common and statistically significant finding $(P<0.05)$. Chi-squared tests showed that all these criteria, except
Also, more males (27.3\%) were exercising than females (17.3\%), and this sex difference was statistically significant $(P$ $<0.02)$. Self-reported cigarette smoking among males (11.6\%) and females (3.5\%) was not associated with an increased risk of metabolic syndrome in this study.

\section{Discussion}

The prevalence of chronic diseases is increasing worldwide. In many developing countries, the growing epidemic of chronic disease disrupts health planning and overwhelms the already underresourced health care systems [16].

While the definition of metabolic syndrome continues to evolve, it is generally recognized as a constellation of risk factors that includes abdominal obesity, glucose intolerance, hypertension, dyslipidaemia and abnormalities in peripheral glucose and fatty acid utilization [17]. The 3 most commonly used sets of criteria for the identification of metabolic syndrome are the WHO, ATP-III and IDF guidelines. The sensitivity and specificity of each of these in detecting metabolic syndrome in the population is currently under debate [18].

Metabolic syndrome may amplify hypertension-related cardiac and renal changes over and above the potential risk of each risk factor in isolation [19]. The Women's Ischemia Syndrome Evaluation(WISE) study of 780 women showed that metabolic syndrome was significantly associated with a higher risk of death or major cardiovascular event in the subsequent 3 years [20].

The 3 key findings of our study are: the frequency of metabolic syndrome (according to ATP-III criteria) (65.2\%) in our sample of hypertensive patients was much higher than previously reported; metabolic syndrome was more common in females than in males; and metabolicsyndromewas more common 


$\begin{aligned} & \text { Table 4 Frequency of metabolic syndrome according to Adult Treatment Panel-III } \\
& \text { (ATP-III) criteria by sex }\end{aligned}$
\begin{tabular}{|lcccccc} 
Diagnosis by ATP-III criteria & $\begin{array}{c}\text { Males } \\
(\boldsymbol{n}=\mathbf{1 4 3})\end{array}$ & $\begin{array}{c}\text { Females } \\
(\boldsymbol{n}=\mathbf{2 0 2})\end{array}$ & \multicolumn{2}{c}{$\begin{array}{c}\text { Total } \\
(\boldsymbol{n}=\mathbf{3 4 5})\end{array}$} \\
& No. & $\%$ & No. & $\%$ & No. & $\%$ \\
\hline Metabolic syndrome & 76 & 53.1 & 149 & 73.8 & 225 & 65.2 \\
Without metabolic syndrome & 67 & 46.9 & 53 & 26.2 & 120 & 34.8 \\
\hline
\end{tabular}

Difference between males and females was statistically significant $(\mathrm{P} \leq 0.05)$.

in older than in younger patients. Our result in Jordan (65.2\%) was almost twice as high as that reported among Kuwaiti patients with hypertension (34\%) [5]. Furthermore that study also found that the older age group and females had a significantly higher frequency than younger age groups or males.

A community-based national epidemiological health survey in Saudi Arabia also showed that people aged $30-70$ years had an overall adjusted frequency of metabolic syndrome (by ATP-III criteria) of $39.3 \%$, with a higher rate among females (42\%) than males (37\%) [6].

When 3 different international protocols were used to categorize metabolic syndrome in our sample, the frequency varied substantially. The IDF and ATP-III criteria identified $64.9 \%$ and $65.2 \%$ of the sample with metabolic syndrome respectively, while WHO criteria identified only $26.9 \%$. Despite the differences that exist when using the 3 criteria of metabolic syndrome, the frequency in our study was higher than that of other studies in the Arab region and worldwide [5-8].

\begin{tabular}{|c|c|c|c|c|c|c|c|}
\hline \multirow[t]{2}{*}{ ATP-III criteria } & \multicolumn{2}{|c|}{$\begin{array}{c}\text { Males } \\
(n=76)\end{array}$} & \multicolumn{2}{|c|}{$\begin{array}{l}\text { Females } \\
(n=149)\end{array}$} & \multicolumn{2}{|c|}{$\begin{array}{c}\text { Total } \\
(n=225)\end{array}$} & \multirow[t]{2}{*}{$P$-value } \\
\hline & No. & $\%$ & No. & $\%$ & No. & $\%$ & \\
\hline Diabetes mellitus & 39 & 51.3 & 56 & 37.6 & 95 & 42.2 & 0.03 \\
\hline Obesity (high WC) & 58 & 76.3 & 139 & 93.3 & 197 & 87.6 & $<0.001$ \\
\hline High TG & 56 & 73.7 & 100 & 67.1 & 156 & 69.3 & 0.19 \\
\hline Low HDL-C & 41 & 53.9 & 108 & 72.5 & 149 & 66.2 & $<0.01$ \\
\hline
\end{tabular}

Difference between males and females was statistically significant $\left(\mathrm{P}_{\leq} 0.05\right)$.

$W C=$ waist circumference; $T G=$ triglycerides; $H D L-C=$ high-density lipoprotein cholesterol . regular physical activity — may be implicated in the high frequency of metabolic syndrome in patients with hypertension. Partial support for this hypothesis is seen by the findings that patients with metabolic syndrome were less likely to exercise than those without metabolic syndrome; females were also less likely to exercise than males and more likely than males to exhibit each component of the metabolic syndrome.

The patients in this study were representative of an urban population in the capital of a developing country, where lifestyles are rapidly changing into a more westernized form. Replication of this study in a rural area would be beneficial.

\section{Conclusions}

Metabolic syndrome is present in a high proportion of our sample ofpatientswith hypertension. Furthermore, metabolic syndrome seemed to be more common in older patients and in women.

An effective action plan is needed to combat metabolic syndrome in order to prevent its consequences and to contain the costly management of its complications. Simple but active measures for health promotion, such as adoption of healthier eating habits, increased physical activity and maintenance of normal body weight should accompany vigorous management and control of blood pressure.

\section{Acknowledgements}

The authors wish to acknowledge the valuable statistical assistance of $\mathrm{Dr}$ Diana Ma'sad and Dr Majdi Affaneh for their material contribution to the design of the study and the analysis. 


\section{References}

1. Expert Panel on Detection, Evaluation, and Treatment of High Blood Cholesterol in Adults. Executive summary of the third report of the National Cholesterol Education Program (NCEP) Expert Panel on Detection, Evaluation, And Treatment of High Blood Cholesterol in Adults (Adult Treatment Panel III). Journal of the American Medical Association, 2001, 258:2486-97.

2. Schillaci $G$ et al. Prognostic value of the metabolic syndrome in essential hypertension. Journal of the American College of Cardiology, 2004, 4310:1817-22.

3. European Society of Hypertension-European Society of Cardiology Guidelines Committee. 2003 European Society of Hypertension-European Society of Cardiology guidelines for the management of arterial hypertension. Journal of hypertension, 2003, 21:1011-53.

4. Braunwald E et al., eds. Braunwald's heart disease: a textbook of cardiovascular medicine, 7th ed. Philadelphia, Saunders, 2005:1953.

5. Sorkhou El et al. Prevalence of metabolic syndrome among hypertensive patients attending a primary care clinic in Kuwait. Medical principles and practice, 2004, 131:39-42.

6. Al-Nozha M et al. Metabolic syndrome in Saudi Arabia. Saudi medical journal, 2005, 26:1360-6.

7. Abdul-Ghani MA et al. High frequency of pre-diabetes, undiagnosed diabetes and metabolic syndrome among overweight Arabs in Israel. Israel Medical Association journal, 2005, 7:143-7.

8. Cameron AJ, Shaw JE, Zimmet PZ. The metabolic syndrome: frequency in worldwide populations. Endocrinology and metabolism clinics of North America, 2004, 33(2):351-75.

9. Kozan $\mathrm{O}$ et al. Prevalence of the metabolic syndrome among Turkish adults. European journal of clinical nutrition, 2007, 61(4):548-53.

10. Ozsahin AK et al. Prevalence of the metabolic syndrome in a Turkish adult population. Diabetes nutrition and metabolism, 2004, 17(4):230-4

11. Soysal A et al. The prevalence of metabolic syndrome among young adults in Izmir, Turkey. Anadolu kardiyoloji dergisi, 2005, 5(3):196-201
12. Ajlouni $\mathrm{K}$, Jaddou $\mathrm{H}$, Batieha A. Diabetes and impaired glucose tolerance in Jordan: prevalence and associated risk factors Journal of internal medicine, 1998, 244:317-23.

13. Ajlouni $\mathrm{K}$, Jaddou $\mathrm{H}$, Batieha A. Obesity in Jordan. International journal of obesity and related metabolic disorders, 1998, 22:624-8.

14. Obesity: Preventing and managing the global epidemic. Report of a WHO consultation on obesity. Geneva, World Health Organization, 1998.

15. Definition, diagnosis and classification of diabetes mellitus and its complications. Report of WHO consultation: part 1: diagnoses and classification of diabetes mellitus. Geneva, World Health Organization, 1999

16. Cardiovascular death and disability can be reduced more than 50 per cent. Geneva, World Health Organization press release WHO/83, 17 October, 2002.

17. Czernichow $S$ et al. Metabolic syndrome in relation to structure and function of large arteries: a predominant effect of blood pressure. A report from the SU.VI.MAX vascular study. American journal of hypertension, 2005, 18(9 Pt 1):1154-60.

18. Peters A. The broadening domain of the metabolic syndrome. Medscape, 27 July, 2005 (http://cme.medscape.com/ viewarticle/508282? rss, accessed 4 October 2009).

19. Mule G et al. Influence of metabolic syndrome on hypertension related target organ damage. Journal of internal medicine, 2005, 257:503-13.

20. Kip KE et al. Clinical importance of obesity versus the metabolic syndrome in cardiovascular risk in women: a report from the Women's Ischemia Syndrome Evaluation (WISE) study. Circulation, 2004, 109:706.

21. Yasein N. Cardiovascular risk and anthropometric measurement in women attending family practice. Jordan medical journal, 2005, 39:106-11.

22. Després JP, Lemieux I, Prud'homme D. Treatment of obesity: need to focus on high risk abdominally obese patients. British medical journal, 2001, 322:716-20. 